\section{Use of a Titanium Mesh "Shelter" Combined with the Soft Tissue Matrix Expansion (Tent Pole) Grafting in the Reconstruction of a Severely Resorbed Edentulous Mandible. Technical Note.}

\author{
Cássio Edvard Sverzut, Alexandre Elias Trivellato, Alexander Tadeu Sverzut
}

Department of Oral and Maxillofacial

Surgery and Periodontology,

School of Dentistry of Ribeirão

Preto, USP - University of São

Paulo, Ribeirão Preto, SP, Brazil

Correspondence: Dr. Cássio Edvard

Sverzut, Avenida do Café, s/

$\mathrm{n}^{\circ}$, Campus Universitário da USP,

14040-904 Ribeirão Preto, SP,

Brasil. Tel: +55-16-3315-3980.

e-mail: cesve@forp.usp.br

\begin{abstract}
Patients wearing complete dentures for a long time usually exhibit lack of bone and keratinized mucosa in the bearing area due to bone resorption. The patients suffering from this phenomenon usually have unstable and non-retentive complete denture, which result in constant trauma to the mucosa, pain, functional limitations and worsening of facial esthetics. An innovative technique has been described in which a novel surgical approach using osseointegrated dental implants as "tent poles" was applied concomitant with particulate autogenous bone graft. The authors claim that the control and maintenance of the surgically expanded soft tissue volume should prevent graft resorption in the long term. Nevertheless, resorption of the bone graft is usually more significant where the bone mass is poorer, in the mandibular body. This paper describes a case of severely resorbed edentulous mandible in which the "tent pole" technique was applied with some modifications. Use of the titanium mesh "shelters" and two additional implants was effective in "protecting" the bone graft in the posterior portion of the mandibular body increasing bone mass volume in this area. Furthermore, we believe that this kind of graft "protection" on the whole residual alveolar ridge can increase the width of bone mass gain optimizing the "tent pole" technique.
\end{abstract}

Key Words: residual alveolar ridge, bone graft, dental implants, mandible.

\section{Introduction}

Patients wearing complete denturess for a long time usually exhibit lack of bone and keratinized mucosa in the bearing area due to bone resorption. Following the extraction of normally erupted teeth, the bone of the residual alveolar ridge also loses functional stimulus resulting in a progressive, cumulative and irreversible bone resorption process (1). Therefore, the patients suffering from this phenomenon usually have unstable and non-retentive complete dentures, which result in constant trauma to the mucosa, pain, functional limitations (e.g. mastication and speech) and worsening of facial esthetics. These problems frequently lead to social limitations and psychological impairment decreasing the patient's quality of life (2).

The number of patients presenting severely reabsorbed edentulous mandible and searching for implant-based dental rehabilitation has increased in the last decades. Many surgical techniques involving hard and soft tissue handling are proposed in the scientific literature in order to maximize the prosthetic procedures in these cases. Some of those surgical techniques have been proposed aiming both to aid the prosthetic rehabilitation and to increase the mandible bone mass. An important alternative is the preprosthetic reconstructive surgery using autogenous bone graft previous or concomitant to the placement of osseointegrated dental implants (1-7).

Marx et al. (2) described an innovative technique in which a novel surgical approach using osseointegrated dental implants as "tent poles" was applied concomitant with particulate autogenous bone graft. The authors claim that the control and maintenance of the surgically expanded soft tissue volume should prevent graft resorption in the long term. Our research group has applied this technique since 2004 and agrees with those authors that the technique offers predictable long-term reconstruction of the severely resorbed mandible without the complication observed in other approaches. Nonetheless, resorption of the bone graft is usually more significant where the bone mass is poorer, in the mandibular body. This occurrence confirms the "functional matrix" or "soft tissue matrix" concept claimed by the authors because in this area the "protection" of the osseointegrated dental implants is lower.

This article describes a case of severely resorbed edentulous mandible in which the "tent pole" technique was applied with some modifications.

\section{Case Report}

A 69-year-old White woman presented to the Clinic of Oral and Maxillofacial Surgery at the School of Dentistry of Ribeirão Preto at the University of São Paulo, Brazil, 
complaining of impairment of her masticatory function associated with the instability of the lower complete denture.

The patient revealed uneventful medical history. The clinical exam revealed edentulism in both arches, while the mandibular arch presented severe resorption resulting in denture instability and chronic trauma to the oral mucosa (Fig. 1A).

Cone beam computed tomography (CBCT) scanning showed a mandible with class $\mathrm{VI}$ reduced bone mass, according to Cawood and Howell (1) (Fig. 1B), which turned unpredictable any rehabilitation based only in osseointegrated dental implants. A rapid prototype model (RPM) was obtained, confirming the severity of the mandibular bone loss. First, the RPM was used to establish the positioning of 8 implants previous to the surgical procedure: 6 anterior to the mental foramens as proposed by Marx et al. (2) and 1 on each side distal to those more posterior previously positioned. These additional implants were done foreseeing the mental foramen transposition. Once these positions were established, two replicas of implants measuring $3.75 \times 15.0 \mathrm{~mm}$ were inserted on the RPM. Afterwards, a 2.0-mm titanium mesh was cut, bended border of the ramus' residual alveolar ridge and supported anteriorly the additional implants (Fig. 2A).

The surgical procedure was performed under general anesthesia exactly as proposed by Marx et al. (2), except for
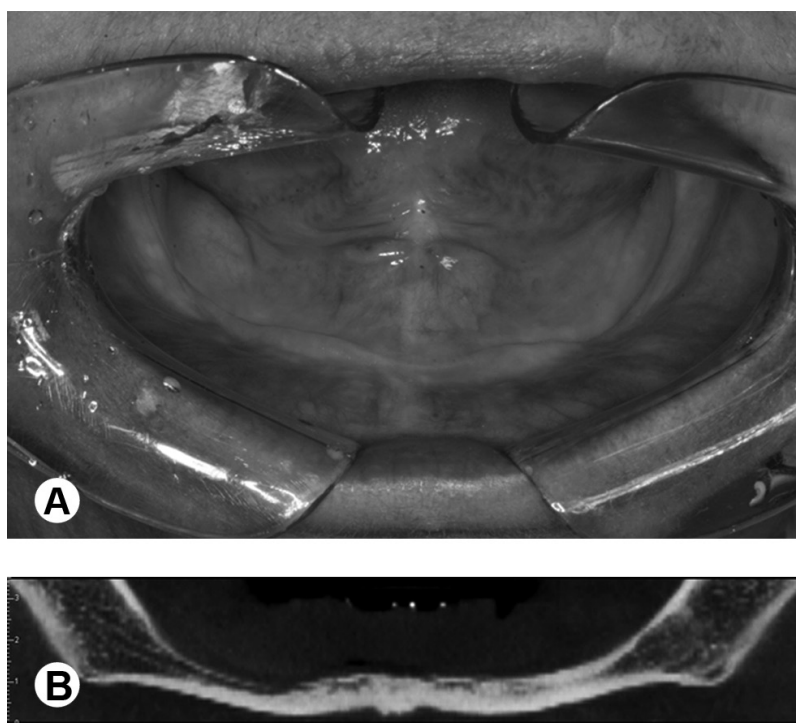

Figure 1. A: Edentulous mandible presenting severe resorption; B. Cone beam computed tomography (CBCT) scanning showing a mandible with reduced bone mass class $\mathrm{Vl}$, according to Cawood and Howell (2).
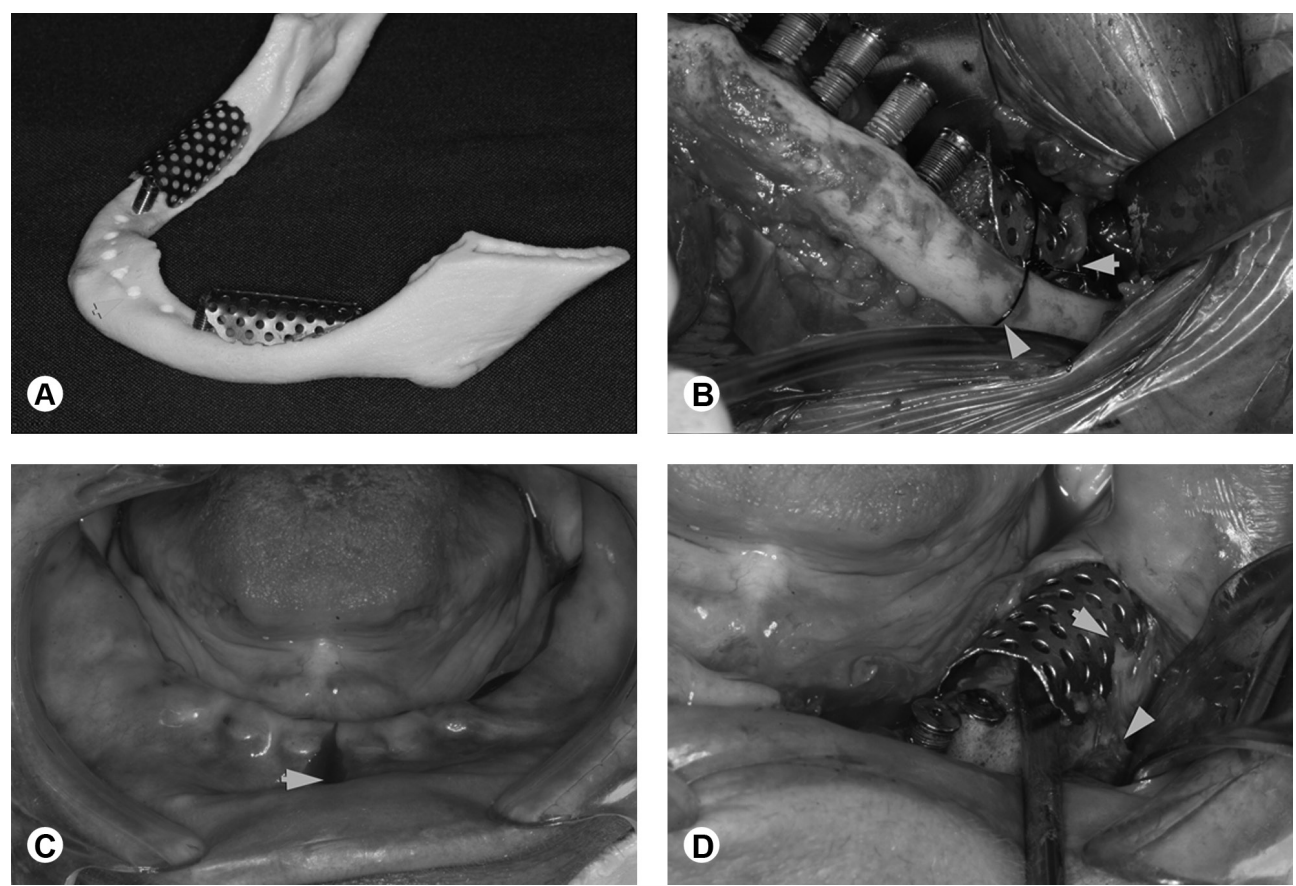

Figure 2. A: The 2.0-mm titanium mesh "shelter" accurately adapted to the anterior border of the ramus, residual alveolar ridge of the RPM and anteriorly supported by the additional implants. It is possible to observe the demarcation (arrow) of the 6 implants positioned as proposed by Marx et al. (2). B: The bended titanium mesh positioned as predicted previously on the RPM. The additional upside down "V" shaped cut on the border (arrow) is allowing the adequate and safe accommodation of the structures related to the mental foramen. The cerclage point (arrowhead) is stabilizing the "shelter" that is anteriorly supported by the additional implant. C: A linear incision extending from one anterior border of the ramus to another splitting the residual keratinized gingiva located more lingually. A relaxing incision extending to the depth of vestibular sulcus (arrow) at the midline was made to facilitate the flap elevation. D: A \#9 Molt periosteal elevator is being applied to elevate and remove the 2.0-mm titanium mesh "shelter". The structures related to the mental foramen (arrowhead) and the upside down "V" shaped cut (arrow) can be noted. 
the two additional implants and the titanium mesh "shelter" that were positioned after implant placement. The bended titanium meshes were positioned as previously foreseen on the RPM, but an additional upside down "V" shaped cut was done on the border of each "shelter" allowing the adequate and safe accommodation of the structures related to the mental foramen after the transposition (Fig. 2B). In order to facilitate the bone graft positioning, a 2-mL disposable plastic syringe in which the anterior portion was cut out was applied as a delivery syringe. Therefore, while the particulate bone graft was positioned under the "shelter", a gentle condensation was also performed. To ensure the stability of the "shelter" one cerclage point on each side was made applying a 3.0-mononylon thread mounted in 3/8 circle needle $30-\mathrm{mm}$ long (Fig. 2B). As proposed by Marx et al. (2) for the top of the implants, a small amount of bone graft was compacted over the titanium mesh surface. The 8 implants measured $3.75 \times 15.0 \mathrm{~mm}$ and the autogenous bone graft was harvested from the anterior iliac crest. During the period of osseointegration and grafting incorporation the patient wore the superior total prosthetic denture, but no kind of prosthesis was allowed in the mandible and the diet consisted of soft food.

The period of implant osseointegration and graft incorporation was uneventful, and 5 months later the implants were exposed intraorally and the cerclage points and "shelters" were removed under local anesthesia without any difficulties.

During the implant exposure and "shelter" removal, a linear incision extending from one anterior border of the ramus to another was made splitting the residual keratinized gingiva located more lingually. A relaxing incision extending to the depth of vestibular sulcus was made at the midline to facilitate flap elevation (Fig. 2C).

A \#9 Molt periostal elevator was applied not only to detach the mucosa covering the "shelters", but also to elevate and remove the "shelters" (Fig. 2D). A thin layer of soft tissue was noted between the "shelters" and the newly formed bone that exhibited clinical features of cortical bone (Fig. 3A). The mentioned soft tissue was not removed except for a small fragment harvested from the left side that was subjected to histological analysis. Another interesting clinical feature was the partial covering of the additional implants by the newly formed bone (Fig. 3B). The overall clinical findings revealed a significant bone mass gain of the residual alveolar process and the border of the resident bone. Incorporated bone graft was evident (Fig. 3C)

Transmucosal healing abutments were placed and two weeks later the patient was referred to the Department of Dental Materials and Prosthesis at the same institution. The histological analysis revealed a soft tissue with abundant fibroblasts and collagenous fibers containing small bone fragments and scarce areas of chronic inflammatory process (Fig. 3D). One year after the dental implant supported
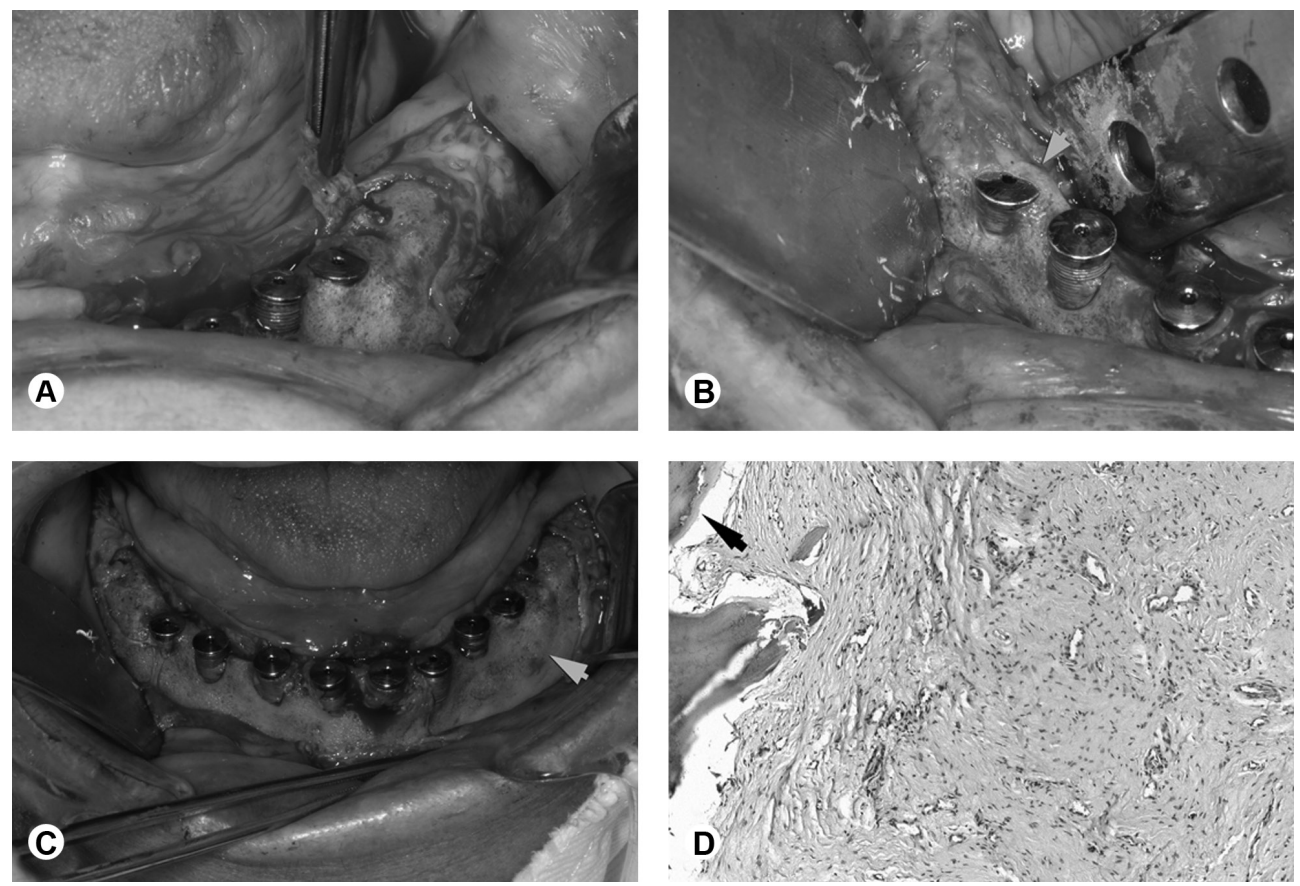

Figure 3. A: Thin layer of soft tissue observed between the "shelters" and the newly formed bone that exhibited clinical features of cortical bone. B: Partial cover of the additional implants by the newly formed bone (arrow). C: A Significant bone mass gain of the residual alveolar process. The border of the resident bone and incorporated bone grafted are evident (arrow). D: Histological analysis revealing a soft tissue with abundant fibroblasts and collagenous fibers containing small bone fragments (arrow) and scarce areas of chronic inflammatory process. 
denture placement, the panoramic radiograph showed a significant gain in the bone height in whole residual alveolar ridge (Fig. 4).

\section{Discussion}

Despite the advancements achieved by dentistry in the last decades, prosthetic rehabilitation of severely resorbed edentulous mandibles still remains a great challenge for the prosthesist and surgeon. An adequate handling of soft tissues usually improves the stability of a total prosthetic denture in the cases where the patient has an adequate residual bone volume. Nonetheless, when the patient has a poor mandibular bone volume it is necessary to associate hard tissue management. The autogenous bone graft is a valuable alternative and the main advantages of this "gold standard" technique are: increase of the mandibular bone volume and improvements of the relationship between mandible and maxilla, shape of the residual alveolar ridge, and function and esthetics of the prosthetic treatment (6).

The use of short implants (up to $7 \mathrm{~mm}$ long) is an alternative to the preprosthetic reconstructive surgery. Two disadvantages of this treatment are: first, unfavorable crown/implant ratio, and second, a higher risk of mandible fracture (5-7).

Prosthetic rehabilitation must aim not only the replacement of the lost normally erupted teeth, but also a gain in the mandible bone mass, mainly in the body region where the bone resorption is generally more intense. Since the life expectancy at birth has increased significantly worldwide over the last decades (8), the treatments involving the reinforcement of the mandible are becoming more important.

Unfortunately, the locomotor system impairment related to the aging can predispose more commonly elderly people to mandible fractures if this bone is edentulous and severely reabsorbed. Therefore, in addition to improving the patients' quality of life by offering an adequate prosthetic rehabilitation, one may expect lower rates of mandibular fractures in these patients if the mandible is reinforced. Further studies should be directed to this issue in order to verify this hypothesis.

The molars are lost usually first than the other teeth in the mandible, exposing the mandibular body to bone resorption for a longer time, resulting in lack of bone volume. The placement of two additional implants and the titanium mesh "shelters" improved the bone mass gain in the mandibular body. Nevertheless, this mandible reinforcement only occurs after the bone graft incorporation. Therefore, during the intraoperative and immediate postoperative periods the mandible is weaker and more predisposed to fractures than before the surgery. The patients must be advised about this potential complication and oriented how to prevent it. The exposition to potential etiologic factors for mandible fracture must be avoided and the consistency of the food must be soft during the osseointegration and graft incorporation period.

The concept of expanding the soft tissue envelope to increase the resorbed alveolar ridge with a titanium mesh was first published in 1985 by Boyne et al. (3) and its use concomitant with the innovative "tent pole" technique described by Marx et al. (2) may potentially optimize the outcomes. The "tent pole" technique has also been applied in ablative defects associated to metastatic mandibular retinoblastoma in pediatric patients (4) and atrophic mandible associated to the ectodermal dysplasia (9), showing also excellent results. Some suggestions have been

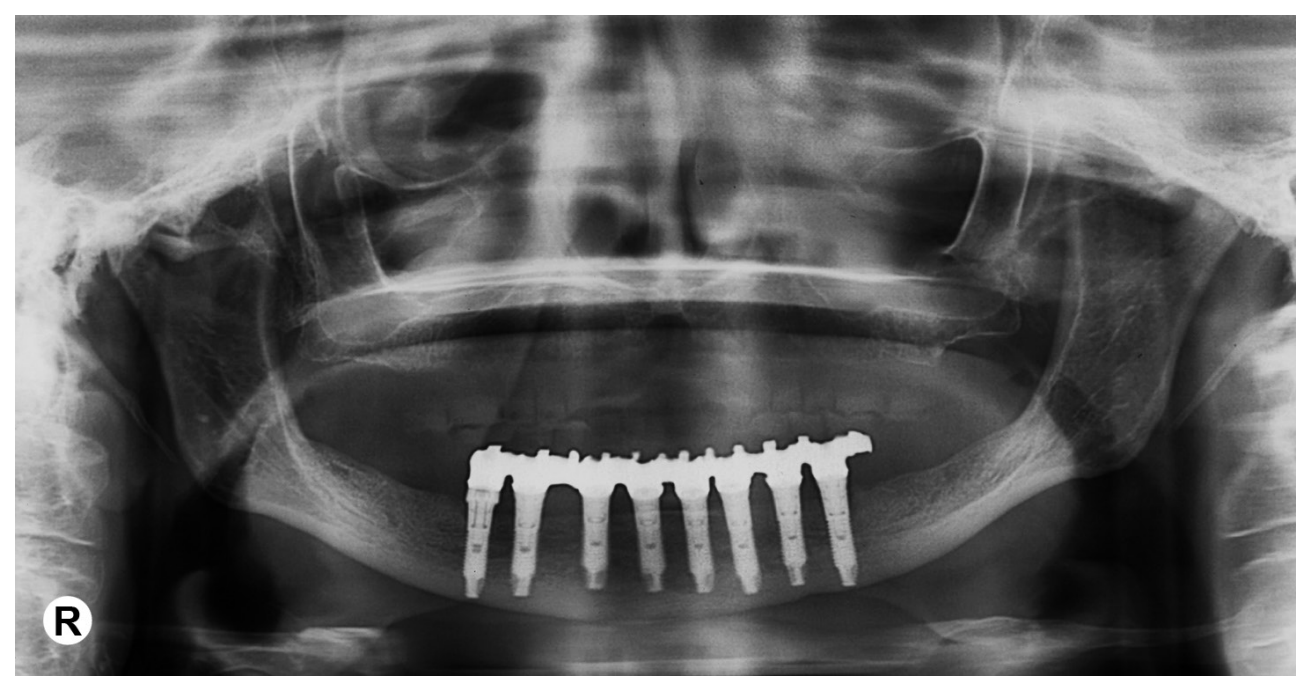

Figure 4. Panoramic radiograph 1 year after the fixed dental implants prosthesis placement showing significant gain in the bone height in whole residual alveolar ride. 
proposed in the scientific literature to aid the adequate implant angulation placement (9). The suggestion in this article is to optimize the gain of bone volume in the mandibular body, where usually the bone volume is poorer.

Although no surgical guide was fabricated by applying the RPM, its use may possibly ensure the proper location and angulation of implants in the arch (10). The mental nerves handling usually leads to sensory deficit and some patients may have physical and emotional problems dealing with it (6), and should be warned about this side effect during the discussion of the treatment plan. Intending to prepare the patients for the expected numbness, Peterson (6) recommended a pretreatment mental nerve block three to four weeks before surgery. According to the author the patients may have the opportunity to evaluate their tolerance of the numbness and their willingness to undergo the augmentation procedure. In the modification proposed in this case, handling of the mental and inferior alveolar nerves is not so invasive because the mandibular canal in this area is usually unroofed due the bone resorption, making it easier to dislodge the nerve from this fissure. The patient in this study reported slight numbness in the immediate postoperative period and significant improvement after 5 months.

The use of the titanium mesh "shelters" and the two additional implants were effective in "protecting" the bone graft in the posterior portion of the mandibular body, increasing the bone mass volume in this area. Furthermore, we believe that this kind of graft "protection" on the whole residual alveolar ridge may improve the width of bone mass gain optimizing the "tent pole" technique.

\section{Resumo}

Pacientes portadores de próteses totais por um longo período geralmente apresentam perda significativa de osso do processo alveolar e de mucosa ceratinizada na área chapeável devido ao processo de reabsorção óssea associada com a perda de função. Estes pacientes geralmente possuem próteses totais sem retenção e estabilidade, o que resulta em trauma crônico à mucosa, limitações funcionais e piora da estética facial. Uma técnica cirúrgica inovadora foi descrita na qual implantes osseointegráveis são posicionados em forma de "pilares" conjuntamente com enxerto ósseo autógeno particulado. Os autores afirmam que o controle e manutenção do volume tecidual obtido cirurgicamente diminui a perda em volume do enxerto ósseo utilizado. Entretanto esta reabsorção geralmente ocorre com maior intensidade onde a massa óssea é mais pobre, ou seja, em corpo mandibular. Este artigo descreve um caso onde uma mandibula severamente reabsorvida foi reconstruida utilizando-se a técnica de "tent pole" com algumas modificações propostas pelos autores. 0 uso da malha de titânio em forma de "cabana" e dois implantes dentários osseointegráveis adicionais contribuíram para "proteger" o enxerto ósseo autógeno na região posterior do corpo mandibular aumentando o volume ósseo na região. Adicionalmente, nós acreditamos que o uso deste tipo de proteção em todo rebordo alveolar residual pode melhorar o ganho de massa óssea otimizando, portanto, a técnica original de "tent pole".
Stomatology and Physiology of the Dental School of Ribeirão Preto, University of São Paulo for the histological assistance and the Center of Technology of the Information "Renato Archer" linked to the Ministry of Science and Technology for supplying the mandible rapid prototype model.

\section{References}

1. Cawood JI, Howell RA. A classification of the edentulous jaws. Int J Oral Maxillofac Surg 1988;17:232-236.

2. Marx RE, Shellenberger T, Wimsatt J, Correa P. Severely resorbed mandible: Predictable reconstruction with soft tissue matrix expansion (Tent Pole) grafts. J Oral Maxillofac Surg 2002:60:878-888.

3. Boyne PJ, Cole MD, Stringer D, Shafqat JP. A technique for osseous restoration of deficient edentulous maxillary ridges. J Oral Maxillofac Surg 1985;43:87-91.

4. Fenton CC, Nish IA, Carmichael RP, Sàndor GKB. Metastatic mandibular retinoblastoma in a child reconstructed with soft tissue matrix expansion grafting: A preliminary report. J Oral Maxillofac Surg 2007;65:2329-2335.

5. Moses 0 , Nemcovsky CE, Langer $Y$, Tal H. Severely resorbed mandible treated with iliac crest autogenous bone graft and dental implants: 17-year follow-up. Int J Oral Maxillofac Implants 2007;22:1017-1021.

6. Peterson $\amalg$. Augmentation of the mandibular residual ridge by a modified visor osteotomy. J Oral Maxillofac Surg 1983;41:332-338.

7. Verhoeven JW, Cune MS, Terlou M, Zoon MA, de Putter $C$. The combined use of endosteal implants and iliac crest onlay grafts in the severely atrophic mandible: a longitudinal study. Int J Oral Maxillofac Surg 1997;26:351-357.

8. WHO. Data | World Health Organization. Life expectancy at birth (years). Available from: http://data.un.org/Data.aspx?q=expectancy +of+lifectd=WHO\&f=MEASURE_CODE\%3aWHOSIS_000001. Latest access: January 27, 2015.

9. Lypka M, Yarmand D, Burstein J, Tso V, Yamashita DD. Dental implant reconstruction in a patient with ectodermal dysplasia using multiple bone grafting techniques. J Oral Maxillofac Surg 2008;66:1241-1244.

10. Kudyba PS, Loetscher CA, Perciaccante VJ, Jones CT, Cantrell $\mathrm{JH}$. The fabrication and use of an extraoral surgical guide for implant placement coincident with soft tissue matrix expansion grafts: clinical report. J Prosthet Dent 2006;96:227-232.

Received February 5, 2014 Accepted November 19, 2014

\section{Acknowledgements}

Prof. Dr. Luiz Guilherme Brentegani from the Department of Morphology, 